\title{
ARTICLES
}

\section{China's evolving role and approach to international peacekeeping: The cases of Mali and South Sudan}

\author{
Theo Neethling ${ }^{1}$ \\ Department of Political Studies and Governance \\ University of the Free State, South Africa \\ neethlingtg@ufs.ac.za
}

\begin{abstract}
China's expanded involvement in post-Cold War United Nations (UN) peacekeeping operations coincided with Beijing's efforts in the early 2000s to expand its economic and diplomatic influence globally through trade and diplomatic links. Towards the mid-2000s, China was involved in all seven UN peacekeeping operations on the African continent. At the same time, Beijing's views on peacekeeping have consistently been premised on state sovereignty and the associated principle of non-intervention and noninterference in the affairs of other states. However, as China's strategic and material interests have become more integrated with the African continent, Beijing has been compelled more and more to consider its national (economic) interests and to protect those interests. Consequently, China's growing involvement in peacekeeping has evolved and become increasingly more difficult to reconcile with the country's historical commitment to noninterventionism, as specifically evident in recent Chinese peacekeeping involvement in Mali and South Sudan. Furthermore, the sending of Chinese combat forces to Mali and South Sudan suggests that China has become more comfortable with UN combat operations under certain situations.
\end{abstract}

\footnotetext{
${ }^{1}$ The author wishes to note that this article is based upon work supported financially by the National Research Foundation (NRF) of South Africa. Any opinion, findings and conclusions or recommendations expressed in this material are those of the author and therefore the NRF does not accept any liability in regard thereto.
} 


\section{Introduction}

The People's Republic of China's (hereafter 'China') global influence has been expanding in many ways. One area where China is taking a leading global role is in the area of UN peacekeeping. After all, China is by far the largest troop-contributing nation compared to the other permanent members of the UN Security Council. This is also applicable and of great relevance to the role of China on the African continent.

China is currently Africa's largest trading partner. Practically, this means that China is Africa's main export market while also its largest source of imports (Romei, 2015). Moreover, China-as an emerging superpower-has undoubtedly presented itself as a most important security actor on the African continent. This development has virtually brought an end to the time where the US, France and Britain dominated foreign influence on the continent. Moreover, China's increasing involvement with the African continent over the past 15 to 20 years is indicative of the remarkable transformation of the country's growing international footprint and so is the deepening and broadening of its involvement in UN peacekeeping operations. Significantly, in recent years, China has not hesitated to become involved in two of the most dangerous UN peacekeeping missions on the African continent, namely in Mali and South Sudan.

While China has a considerable economic footprint on the African continent, it has always remained firm in its adherence to a strict policy of non-intervention (or non-interference) in the affairs of African states. China's non-interventionism relates to the inviolability of state sovereignty as a rhetorical backbone of Chinese foreign policy that dates from Western and Japanese intervention and imperialism in China (Richardson, 2013). However, this policy has been under pressure where China has extensive interests. This is particularly clear in the field of UN peacekeeping. For many years, Chinese peacekeepers have assumed mainly relatively safe roles, and conducted tasks such as constructing infrastructure, guarding hospitals and administering medicine at clinics and hospitals. Premised on its policy stance of non-interference, Chinese troops have never been put in a position or been allowed to use force in any offensive manner. In this regard, China has deployed engineers, logistical units, medical units and transport functionaries to UN peacekeeping operations in Africa, but not combat forces. In so doing, China has tried to convince African states and the international community that its policy objectives are well intentioned and non-offensive. 
However, a change - even watershed - in China's approach became evident when Beijing decided to send combat soldiers to two UN peacekeeping operations on African soil: first in Mali (2013) and, thereafter, South Sudan (2014). While the sending of combat forces to Mali indicated that China was becoming more comfortable with "UN combat missions under certain situations" (Lanteigne, 2014, p. 18), China's policy of non-intervention has even been put to the test in South Sudan (Allison, 2015; Richardson, 2013). As Louw-Vaudran (2015) strikingly states, "(t)rying to make peace and build a stable Africa would imply some form of political involvement over the longer term".

Following the abovementioned developments with regard to Mali and South Sudan (which will be further examined in the sections below), the pressing question is whether this implies the end of China's policy of noninterventionism. This article is based on research that aimed to focus on matters relating to the point that China has long been a major, but quiet, contributor to UN peacekeeping, but which is now also a power that is assuming greater global responsibilities in a much more assertive manner. Moreover, as China's interests on the African continent are on the increase, China is compelled to consider its national interest and now seems willing to protect that interest more assertively than before. These matters will be reviewed in the sections below. In view of this, a central argument of this paper is, first, that Beijing has emerged as a significant actor in international peacekeeping operations in general and Africa in particular. Second, that China's expanding role in UN peacekeeping operations over the last two decades has helped Beijing to craft a positive and constructive image and reputation in the international arena. Third, that China's emerging role on the African continent is part of a pragmatic reorientation and reassessment in Chinese policy-making circles, specifically where Beijing's political interests and related investments are at stake.

The first part of this article reviews the historical context of China's gradual entry into the peacekeeping arena, while the second part examines China's economic interest in and involvement on the African continent, and the strategic elements underpinning its peacekeeping actions. The latter specifically relates to changes in China's foreign affairs and what is considered a shift away from China's traditional non-interventionist foreign policy approach, towards a more assertive or proactive role in dealing with actors on the African continent. 


\section{Contextualising China's contributions to UN peacekeeping operations}

In a world that is changing dramatically and ever more quickly, perceptions, analyses and policies can never be static. As in other parts of the international community, the Chinese government also realised that the Cold War-era perceptions of international security had to change and be refocused, especially given the challenges posed by phenomena such as international terrorism and the destabilising effects of state collapse. As in other parts of the world, 'non-traditional' security challenges have become a part of Chinese contemporary military strategy. This is of particular relevance to the African continent and, since the mid-2000s, China has increasingly been engaged in "long distance manoeuvres" on the African continent as part of UN peacekeeping operations (Lanteigne, 2014, p. 7).

Yet, China has not always assumed a positive stance on UN peacekeeping operations. Looking back, the Chinese situation in relation to UN peacekeeping can be described as a shift "from ardent opposition in the 1970 s to avid support in the 2000s" (Wang, 2013). For about four decades, Beijing was highly sceptical of the UN's peacekeeping role, specifically because the Chinese leadership thought that the UN had been utilised for the Korean War (1950-1953) to legitimise and sanction actions that were viewed by China as aggressive military intervention (Ayenagbo et al., 2012) in a conflict where Chinese forces fought UN forces under a US command. Another reason for China's reluctance was its belief that the sovereignty of nations gave nations an inherent right to control their own affairs without intervention from third parties (Rogers, 2007).

Following the end of the Cold War and the significant changes to the international community, Chinese leaders moved to a position of active cooperation in UN activities. According to Wang (2013), the benefits of "demonstrating global responsibilities, extending economic and diplomatic influence and obtaining operational military experience," convinced Chinese leaders to make a "strategic change of heart".

In this context, the limited number of Chinese peacekeepers deployed to UN missions from the 1970s to the 1990s turned into a dramatic surge in Chinese peacekeeping participation in the 21 st century. From January 2001 to January 2009, the number of Chinese 'Blue Helmets' deployed to UN missions increased from fewer than 100 in 2000 to close to 2000 in 2008 (UN Department of Peacekeeping Operations, 2001, p. 1; UN Department of Peacekeeping Operations, 2008, p. 1).

After joining the UN Special Committee on Peacekeeping Operations and setting a new tone for Chinese support for UN peacekeeping in 1988, China deployed 20 military observers to the UN Transition Assistance 
Group (UNTAG) to assist with the monitoring of elections in Namibia. This was followed by the deployment of five Chinese observers to the UN Truce Supervision Organisation (UNTSO) in the Middle East. A significant break with the past came when China contributed 400 engineering troops and 49 military observers to the UN Transitional Authority in Cambodia (UNTAC) in 1992 (Gill \& Huang, 2013, p. 141). What is of interest is that, although China started to move beyond its previous reluctance toward UN peacekeeping operations and began to make personnel contributions to such operations, Beijing clearly had a marked preference for sending observers only. Chinese engineering contributions to UNTAC came as an exception, when two separate Chinese engineer battalions were committed, and thus became the first Chinese 'Blue Helmets' in the common use of this concept (Lanteigne, 2014, p. 5).

The abovementioned increase in contributions to UN peacekeeping operations also turned into more diversified contributions, such as transport and medical support. In 1999, China started to deploy civilian police to East Timor, followed by more police deployments to Haiti, Liberia, South Sudan and Timor Leste. In accordance with its public diplomacy rhetoric that Chinese peacekeepers were deployed with foreign considerations that corresponded with China's traditional friendship with developing nations, as well as peaceful development and cooperation, the Chinese Ministry of Defence reported in 2011 that their peacekeepers had built and repaired over $8700 \mathrm{~km}$ of roads and 270 bridges. They also cleared over 8900 mines and various devices, and transported over 600,000 tons of cargo across a total distance of 9.3 million kilometres. In the medical field, 79,000 patients were treated (Gill \& Huang, 2013, p. 142; Lanteigne, 2014, p. 6). Viewed from an International Relations theoretical perspective China's peacekeeping actions can be associated with key aspects of both the liberal and constructivists schools of thought. After all, the above-mentioned Chinese contributions seem to be based on cooperation among states (liberalism) as well as friendship premised on processes of social practice, interaction and shared ideas among states (constructivism). From a more general political and global perspective, China's involvement in the peacekeeping operations of the UN also shows how this emerging superpower is deliberately and systematically using peacekeeping as a diplomatic instrument, and how it is crafting its international public profile as that of a responsible major power (Wang, 2013).

Unlike the US, which operates 700 to 800 military bases abroad, China does not have a network of global military bases, but today exercises its global presence through involvement in several UN peacekeeping 
operations (Campbell-Mohn, 2015). In August 2013, China was ranked among the top 20 troop-contributing nations in the world and it contributed far more than any of the other four permanent members of the UN Security Council (UN Department of Peacekeeping Operations, 2013, pp. 1-3). In this regard, China contributed 32 civilian police, 40 military experts and 1703 troops to UN missions worldwide - a total of 1775 UN peacekeeping personnel. Three years later, in August 2016, China was listed as the 11th largest contributor to UN peacekeeping, with 2639 Chinese peacekeepers deployed to UN missions worldwide. This includes 173 civilian police, 30 military experts and 2435 troops (UN Department of Peacekeeping, 2016a, pp. 1-3). To put this into perspective, France was ranked 2nd among the Security Council permanent members with its contribution of 38 civilian police, 8 military experts and 821 troops - a total of 867 UN peacekeeping personnel (UN Department of Peacekeeping Operations, 2016a, pp. 1-3).

What is of interest is that China is not only significantly contributing troops to UN peacekeeping operations, but is also listed as one of the top financial contributors (See Table 1).

Table 1 Top 10 providers of UN peacekeepers 2016

$\begin{array}{clr}\text { 1. United States of America } & 28.57 \% \\ \text { 2. China } & 10.29 \% \\ \text { 3. Japan } & 9.68 \% \\ \text { 4. } & \text { Germany } & 6.391 \% \\ \text { 5. } & \text { France } & 6.31 \% \\ \text { 6. United Kingdom } & 5.80 \% \\ \text { 7. } & \text { Russian Federation } & 4.01 \% \\ \text { 8. Italy } & 3.75 \% \\ \text { 9. Canada } & 2.92 \% \\ \text { 10. Spain } & 2.44 \%\end{array}$

Source: UN Department of Peacekeeping, 2016b

Against this background, Silalahi (2016) argues that there has been an overall shift in China's foreign policy style, especially since Xi Jinping became the Chinese head of state in 2012. This shift is very evident in the field of peacekeeping and can be understood and described as a policy that is "more self-assured, more pragmatic and converges better with global norms" (Silalahi, 2016). In this way China is shaping its image and reputation in the global arena. 


\section{Drivers of Chinese peacekeeping contributions and new policy dynamics}

Silalahi (2016) maintains that China's decision to increase its role in international peace and security, specifically UN peacekeeping operations, is closely linked with how the Chinese government is shaping the country's reputation and image in the international community. As far as the motivations underlying Chinese peacekeeping contributions are concerned, Gill \& Huang (2013, p. 141) suggest that Chinese peacekeepers have been deployed largely as a result of factors outside realist assumptions (that is, national interest and power projection). Chinese leaders have been specifically concerned with China's image and reputation, especially after the Tiananmen incident in 1989. Rogers (2007) concurs with this view and argues that the People's Liberation Army (PLA) needed to restore a politically congenial relationship with the broader international community. This relationship could be restored through actions ranging from disaster relief to participation in UN peacekeeping. In addition, China also sought regional confirmation of its status as a peaceful neighbour (Gill \& Huang, 2013), and thus projected an image of a peace-loving and responsible major power. This means that its involvement in peacekeeping operations presented an opportunity to place China in a favourable light internationally, as well as domestically, which has been important to China and its armed forces (Rogers, 2007). Campbell-Mohn (2015) even asserts that China has been seeking to utilise peacekeeping as an instrument of soft power with a view to gaining international goodwill in order to soften responses to its provocative actions in the South China Sea.

What is clear from the preceding discussion is that there has been a sea change in China's attitude towards international peacekeeping operations. China's foreign policies have evolved from outright rejection of UN peacekeeping operations (1970s) to reluctant participation (1980s), to prolonged involvement in peacekeeping operations. What is also important is that there have always been limitations to China's involvement in peacekeeping operations (Taylor, 2008, p. 6). As already mentioned, Beijing's views on international peacekeeping were based on a strong respect for state sovereignty and the principle of non-interference in the internal politics of other countries (Shelton, 2008, p. 5). Accordingly, China remains principally opposed to actions perceived as interfering in the domestic affairs of states and will only become involved in peacekeeping if the host government concurs. In recent years, Beijing has also remained suspicious and sceptical that interventions carried out in the name of 
'humanitarianism' are motivated by interests other than international solidarity or charity (Taylor, 2008, p. 6).

As China's presence on the African continent has deepened, however, expectations that it must engage less reservedly in the politics of peace and security have also increased (Davies, 2008, p. 3). In other words, China's growing global power status has taken Beijing to a position where it has to contend with expectations that it will play an ever greater role in global affairs, and at the same time deal with considerations of what sovereignty is and when it might be infringed within the framework and discourse relating to intervention and peacekeeping. This has basically necessitated a pragmatic reorientation and reassessment of Beijing's political interests by Chinese decision-makers, who increasingly have to fit their country into the role of a responsible great power and less of a developing country premised on a rigid policy stance of protection of state sovereignty at all costs (Taylor, 2008).

For many years, observers have debated the nature and scope of China's involvement on the African continent as it has sought a more active role in the international system in general and on the African continent in particular. Generally, China has pursued closer ties and stronger relations with non-Western countries, and African states have played an important role in the Chinese stratagem. What also makes this of interest is that many African states-like China - have been under pressure from Western states to liberalise their political systems. These African states have often been more than willing to go along with China's claims that Western demands for democracy and respect for human rights are thinly veiled imperialistic efforts for interfering in the domestic policies and practices of developing states, and thus for undermining their stability and progress (Tull, 2006). The Chinese government has been offering its African partners a mix of political and economic incentives and has successfully managed to drive home the message that increased Sino-African relations will result in a beneficial win-win situation for both entities. This has become a powerful glue between China and Africa and served as common ground for identity building between China and Africa vis-à-vis the 'paternalistic West' (Tull, 2006, pp. 459-461).

A clear indication of change in China's foreign policy and peacekeeping approach towards the African continent became evident in March 2013 when Beijing offered its support for a UN 'offensive brigade' to be deployed to the conflict-ridden eastern parts of the Democratic Republic of the Congo (Lanteigne, 2014, p. 17). The idea was that such a brigade would serve as part of the UN Stabilisation Mission in the Democratic Republic of 
the Congo (known by its French acronym MONUSCO) to confront and disarm the destabilising rebel groups, such as the March 23 Movement (M23). Such a unit was to be created and mandated by the UN, contrary to previous UN peacekeeping protocols, to use force without necessarily being fired upon first (Lanteigne, 2014).

More recently, in September 2015, China's president Xi Jiping offered 8000 soldiers for a UN peacekeeping standby force. This offer was made at the UN headquarters in New York where Xi even agreed with then-US President Barack Obama that both countries should increase their 'robust' peacekeeping commitments, but that they should also try to allay fears that China's growing influence was a threat in world politics (Martina \& Brunnstrom, 2015).

Against this background, Lanteigne (2014) asserts that, as China's involvement in international peacekeeping has developed, there has been a growing realisation that Beijing would have to reconsider its peacekeeping policies and start to prepare itself for the more challenging aspects of international peacekeeping. This includes China's traditional views on the sanctity of state sovereignty and non-intervention.

\section{China's evolving peacekeeping role: The case of Mali}

An indication that China has become more accepting of international interventions under specific conditions (Lanteigne, 2014) relates to Beijing's decision in mid-2013 to send an infantry detachment to serve in the UN Multidimensional Integrated Stabilisation Mission in Mali (MINUSMA) - a vulnerable country haunted by several anti-government military factions and multiple terrorist groups.

The UN deployment in Mali followed the collapse of the state in the north after radical Islamic armed groups initiated a series of attacks against government forces. Deployment was based on a tentative peace agreement between Bamako (the capital and largest city of Mali) and the Tuareg rebels in June 2013. An election was held shortly after in July 2013, but the northern parts remained unstable due to occasional attacks by al-Qaeda in the Islamic Maghreb (AQIM). As the peace agreement was struck, the UN mandated the formation of MINUSMA with a view to re-establishing the Malian state throughout the country (MINUSMA, 2016).

The Chinese detachment of combat forces was the first foreign deployment of Chinese combat troops in an international peacekeeping role (Lanteigne, 2014, p. 10). It was the first time that Beijing had sent a separate protection unit consisting of infantry and special forces to a UN peace mission - not only to protect its own peacekeepers, but UN 
peacekeepers as well (Clingendael, 2015). China's foreign minister, Wang Yi, officially admitted that this marked a shift in Beijing's foreign policy. Chen Jian, head of the UN Association of China, a Chinese think-tank, also stated, "[t]his is a major breakthrough in our participation in peacekeeping ... with this our contribution will be complete. We will have policemen, medical forces, engineering troops and combat troops" (as quoted by Hille, 2013).

China's political and military leaders have thus gradually shown a more flexible foreign policy approach, while also acknowledging that China's need for resources and growing investments has developed to the point where it can no longer avoid sending combat troops to Africa. At the same time, the Chinese government does not want to create the impression that it is redirecting its foreign policy while rising to global power status. In the case of Mali, Beijing was swift to point out that China's commitment to the principles of non-intervention and rejection of military force as a means of conflict resolution remains unchanged. Yet, Foreign Minister Wang also admitted that China had to align its foreign policy with its expanding global interests when it decided to commit combat troops to the crisis in Mali (Hille, 2013; Murray 2013).

This certainly signalled a new direction - even a watershed - in China's engagement in international peacekeeping (Clingendael, 2015). It also indicates that China's security presence at the international level has reached the point where Beijing seems to be comfortable with conducting more offensive UN peacekeeping operations under certain conditions (Lanteigne, 2014, p. 18).

Although the responsibility of the PLA force in Mali was largely confined to a protection role for the MINUSMA headquarters and living areas of the peacekeeping forces, China's willingness to contribute to MINUSMA generally reflects Beijing's increasingly proactive approach to international peacekeeping. This willingness further coincides with the significant fact that, in 2013, China had about 15 times as many international peacekeepers as it did in 2000 (Murray, 2013, p. 2).

As far as the mainspring of China's involvement in UN peacekeeping operations is concerned, Clingendael (2015) contends that there are four general explanations for Chinese involvement in peacekeeping in Africa, namely:

- $\quad$ assuming responsibility as a global actor;

- gaining military experience;

- securing natural resources; and

- facilitating exports. 
Mali is of limited interest as far as the latter two motivations are concerned, as the country has relatively little to offer China in terms of resources and an export market. However, involvement in MINUSMA signals China's emergence as an actor that plays a role as a guarantor of international order. Peacekeeping contributions to MINUSMA also help to protect Chinese civilians and their economic interests in Mali and the broader western African region, and to contribute to regional stability (Clingendael, 2015). In November 2015, three Chinese civilians were killed when 27 hostages lost their lives in an attack on the Radisson Blu Hotel in Mali's capital, Bamako (Tiezzi, 2016). This sparked a strong reaction from the Chinese government and calls for greater emphasis on peace and security in China's engagement with Africa. In other words, security has become an increasingly important concern for China, which coincides with Chinese business interests and a growing number of Chinese nationals living in Africa with a heightened possibility that they might be injured or killed (Louw-Vaudran, 2015). In 2014, the Nigeria-based terrorist group, Boko Haram, attacked a Chinese factory in neighbouring Cameroon, kidnapping ten Chinese nationals, demonstrating that Chinese economic interests and nationals in Africa have in some instances become the targets of extremist organisations (Lanteigne, 2014, p. 180).

Militarily speaking, Chinese involvement in peacekeeping provides important practical benefits for the PLA. The PLA is in a position to fieldtest equipment and obtain first-hand experience in addressing unconventional threats in potentially hostile environments, which enables China to integrate itself into multilateral international operations (Murray, 2013 , p. 3). In Mali specifically, the PLA has the opportunity to engage in counterterrorism operations and develop China's interest in understanding the processes of radicalisation and extremism. Mali is also regarded by Beijing as a safer option than Syria, with a lower chance of possible confrontation with the US around interests in the Middle East (Clingendael, 2015).

China's decision to send infantry troops to Mali, however, exposed Chinese peacekeepers to more dangerous operations than before, and a Chinese member of MINUSMA was among four killed in attacks targeting UN facilities in Gao, Mali in June 2016 (Tiezzi, 2016). Twelve more peacekeepers were injured in the attack, including four Chinese soldiers. The Chinese Foreign Ministry responded swiftly by expressing its "deep condolences to the victims and sincere sympathies to the bereaved families and the injured" (Tiezzi, 2016). The other UN mission to which China has 
deployed force protection units is South Sudan. This is discussed in the following section.

\section{China as peacekeeper and mediator: The case of South Sudan}

Prior to China's deployment of combat troops in Mali, elite Chinese combat troops have also been spotted in South Sudan since 2011. South Sudan, of course, became independent from the rest of Sudan in 2011, after 30 years of war, as part of an international effort to reshape security in the region. Chinese companies saw South Sudan as a great economic prospect, and investment in the oil industry led to the settlement of a significant number of Chinese nationals in the country.

China immediately projected itself as the newly independent South Sudan's strongest foreign partner. Two years after South Sudan's independence, in 2013, civil war broke out in South Sudan between factions relating to the two dominant ethnic groups, the Dinka and the Nuer. Investors were hoping that the situation would stabilise, but this did not happen and the civil war continued unabated under the leadership of the two main political figures in the country, President Salva Kiir (a Dinka) as head of the official government, and (former) Vice-President Riek Machar (a Nuer) as leader of the group of insurgents or rebels (Rotberg, 2016; Vasselier, 2016).

China has been working hard to mediate between the belligerent parties in South Sudan. In contrast with Mali, where Chinese interests are relatively limited-although not insignificant in the African context (see Esterhuyse \& Kane, 2014) - the rationale for Chinese involvement in the crisis in South Sudan is much clearer. As Humphrey (2013) observed, "If China is going to play a large investment role in sub-Saharan Africa, it must be willing to play a security role, too."

In 2014, it was announced that China planned to send about 700 combat troops to South Sudan, where Chinese peacekeepers were deployed as part of the UN Mission in the Republic of South Sudan (UNMISS). Analysts such as Allison (2015) and Lanteigne (2014), regard the sending of Chinese combat troops as a matter of Beijing showing greater leniency in accepting interventions under specific conditions, such as seeking as much consent as possible from local and international actors. Otherwise, this development coincides with the fact that under the leadership of President Xi Jinping, the country has started to make significantly larger contributions and for the first time committed combat troops (Week in China, 2016). What is more, China armed its peacekeepers in South Sudan with advanced weaponry, such as armoured personnel carriers, anti-tank rockets and unmanned 
drones, making it a true combat force with capabilities way beyond selfdefence (Yincai, 2016).

On the one hand, it could be pointed out that China's mediating role in the Sudanese region was not really new in view of the fact that, in 2006, China had already exerted diplomatic pressure on the Sudanese government in Khartoum to permit UN peacekeepers into Darfur. On the other hand, China became the first permanent member of the UN Security Council to commit and deploy troops there (Gill \& Huang, 2013, p. 154), and the deployment of Chinese combat troops in South Sudan indeed brought a deepening of Chinese engagement on the African continent. Moreover, comparatively speaking, on 31 August 2016, the numbers of Chinese peacekeepers deployed to UNMISS expanded to a total of 1066 (UN Department of Peacekeeping 2016c, p. 10), as opposed to a total of 363 Chinese peacekeepers on 31 August 2014 (UN Department of Peacekeeping, 2014).

Four key issues underpin South Sudan's importance to China and motivated Chinese contributions to international peacekeeping in South Sudan (Broga, 2014).

First, China is the main recipient of South Sudan's oil with over 66 per cent of total oil output. Instability and conflict in the country obviously threaten South Sudan's oil output and, since December 2013, conflict between the government and rebels has reduced output by 20 per cent, which partially contributed to oil price hikes to over $\$ 99$ per barrel in January 2014. This coincided with low levels of oil production in Libya and continued violence in Iraq (Broga, 2014).

Second, China is the biggest foreign investor in South Sudanese infrastructure. Since the 1990s, China has made heavy investments of about US\$20 billion in the oil infrastructure of the former (united) Sudan. After the 2011 partition, a pledge was made to invest an additional US\$8 billion in oil infrastructure. Given the Chinese experience of losing US\$8 billion in the Libyan conflict, it needed to avoid a similar experience in South Sudan (Broga, 2014).

Third, historically, Sudan is a long-standing ally of China with diplomatic links dating back to Sudanese independence in 1959. In this sense, South Sudan holds symbolic value for the Chinese government, and the close relationship between the two countries has undoubtedly inspired China's willingness to play a role in protecting stability (Broga, 2014).

What should be especially clear from the above is that China has made large investments in South Sudan and has therefore been unusually proactive in diplomatic efforts to pacify matters in South Sudan, 
particularly after the civil war slashed oil production by a third (Allison, 2015). Vasselier (2016) rightly argues that China's economic interest in South Sudan has required Beijing to become politically engaged in the country, thereby "contradicting its policy of non-interference in local politics". In an unusual move, the Chinese government even began funding several projects for the South Sudanese government, and supported this through the sale of weapons to South Sudan's armed forces, the Sudanese People's Liberation Army (SPLA). The project, known as the Norinco weapons project, was aimed at cementing a strong relationship with the South Sudanese government in order to ensure a trustworthy partnership between the governments of China and South Sudan. The Chinese government even advocated a one-party system to maintain unity and avoid ethnically based politics, thereby effectively supporting the Dinka SPLA against the Nuer rebels, known as the SPLA in Opposition (SPLA-IO) (Vasselier, 2016), which clearly appears to be at variance with its noninterference policy.

Another extraordinary move away from China's traditional foreign policy stance of non-interventionism relates to a visit by Chinese Foreign Minister Wang Yi to South Sudan in January 2015-only weeks after China had committed 700 combat troops to South Sudan. From China's side, the visit was aimed at engaging in discussions with both warring parties in the South Sudanese conflict (led by President Salva Kiir and former Vice-President Riek Machar, respectively) on how to speed up political reconciliation. Also under discussion was the lingering conflict between South Sudan and its northern neighbour, Sudan. In Khartoum, Wang also held discussions with representatives from the regional Intergovernmental Authority on Development (IGAD) on how to promote the peace process in South Sudan. In doing so, China stepped into an unprecedented key mediation role between the conflicting parties in the Sudanese region (Tiezzi, 2015). In this regard, China realised that talking only to the government would not work, and that both main parties to the conflict had to be involved in pursuing peace. President Xi Jinping also offered to send 8000 more Chinese soldiers to help enforce peace in South Sudan, but this was not accepted by the UN and other actors, probably because the South Sudanese government did not support the initiative (Rotberg, 2016; Vasselier, 2016). Furthermore, even though China tends to work bilaterally, in the case of South Sudan Chinese representatives decided to become part of a Joint Monitoring and Evaluation Committee, which monitors the implementation of the 2015 peace agreement. Although the Chinese representatives are currently passively observing the unfolding 
of matters, they are represented in almost all of the weekly or monthly meetings and also engage with the International Monetary Fund's mission to South Sudan as well as the African Union (AU) (Vasselier, 2016).

In response to criticisms that China selfishly protects and pursues its own interests (Tiezzie, 2015), the Chinese government defended its position when Foreign Minister Wang Yi remarked that China has acted not in its own interest, but "on the responsibilities and obligations of a responsible world power". Significantly, he also acknowledged that "wars and conflict hurt the oil industry", which is where China has special interest, but added that damage to the oil industry would hit South Sudanese and Sudanese people hardest (Tiezzi, 2015). He specifically dismissed concerns that China's growing influence in international affairs was a threat (Silalahi, 2016). These developments prompted Richard Poplak, an author and journalist studying China's influence on the African continent to remark:

It comes down to interest. The Chinese have poured billions and billions into South Sudan, so many resources that it's almost baffling. This is a shift in realpolitik: you can't just talk all the time and not carry a big stick. The Chinese realised that (Poplak, cited in Smith, 2014)

To put matters into perspective, when China expanded into Africa in the post-Cold War period, it justified its dealings with illegitimate and dictatorial African leaders on the basis of China's strict adherence to a policy of non-intervention and a commitment to work for positive change in African states. African leaders have also mostly welcomed Chinese investments, which have come without any prescriptive policies or conditions (Tull, 2006; Allison, 2015). African leaders have further considered the Chinese approach a welcome alternative to American conceptions of 'world order' and the 'Washington consensus'. However, as Chinese investments on the African continent have continued to grow, China's stance of non-intervention has become harder to maintain. Beijing has become increasingly aware of its image and even more wary of being seen to support or facilitate pariah states. In addition, it has had to look more carefully at the protection of its growing interests, making peace and security of great concern. Tiezzi (2014) articulates this eloquently: "[a]s China's interests abroad grow, its policy of non-intervention will face more and more challenges. China's vision for a 'New Silk road' [will] see increased Chinese investment and trade in some of the most unstable regions in the world." The number of Chinese working in South Sudan has 
now grown to a figure of 7000 , including Chinese serving as UNMISS peacekeepers (Vasselier, 2016).

From another point of view, it should also be noted that the South Sudanese government has recently requested assistance from China in an effort to ensure its political survival. The national treasury was empty and the government had been unable to pay its civil servants, police and soldiers regularly. It was hoped that China would provide nearly US\$2 billion to redevelop oil fields and rebuild roads and infrastructure (Rotberg, 2016). Specifically, this pertains to a key petroleum-supplying field in the Unity State/Province and an important road between the capital, Juba, and Wau, a major city in the western part of the country. The latter is important, as it will keep the Dinka heartland connected to the South Sudanese capital. Most importantly, what should be noted here is that South Sudan's requests for assistance and funding provided China with substantial leverage and created political opportunities for China to push for peace accomplishments (Rotberg, 2016), effectively steering China away from its traditional nonintervention, non-interference policy stance. By the beginning of 2016, rumours had even spread in Juba that Chinese representatives were calling for the resignation of the South Sudanese Finance Minister, David Deng Athorbei, which, if substantiated, would constitute clear meddling in local politics. At the centre of the story was Note 2016046, signed by China's Ambassador to South Sudan, Ma Qiang. The note, dated 18 May 2016, was addressed to the Sudanese Ministry of Foreign Affairs, and expressed the Chinese government's disappointment in Athorbei's characterisation of China's oil production in South Sudan as exploitive (Vasselier, 2016).

As far as China's involvement in UNMISS is concerned, it should be noted that China's decision to send infantry troops to South Sudansimilarly to the case of Mali-exposed Chinese peacekeepers to more dangerous operations than before. On 10 July 2016, an armoured vehicle carrying Chinese soldiers was shelled. The incident occurred in Juba, and four soldiers were injured and two were killed, making them the second and third Chinese peacekeepers to be killed in 2016 as part of a UN peacekeeping operation in Africa (Week in China, 2016). The Chinese government reacted sharply to the death of these two peacekeepers with the PLA stating that it was "deeply shocked" and strongly condemning the attack on Chinese peacekeepers (Kuo \& Yinyin, 2016).

Finally, from the above it is clear that South Sudan has been a theatre of challenges and opportunities for China. In this volatile and turbulent environment, Beijing felt compelled not only to make a substantial peacekeeping contribution to UNMISS, including deploying combat troops, 
but also to assume a number of new political roles, such as mediating between parties and engaging in peace talks in a multilateral framework. Certainly, this has put Chinese foreign policy principles under pressure and further steered Chinese involvement in international peacekeeping operations into a new context (Vasselier, 2016).

One can thus argue that China's peacekeeping experience in South Sudan over the past years has coincided with a measure of change in China's foreign policy, and tacit recognition from China that some kind of intervention is sometimes needed to protect its strategic interests. Although China's involvement in peacekeeping in South Sudan should not be overestimated or overstated in terms of its scope and extent, it does seem to signal the beginning of a far more assertive role for China in Africa's peace and security issues (Allison, 2015). It could safely be argued that a rethink of China's foreign policy had taken place. China is indeed now operating differently in Africa, as it can no longer take an arm's-length approach towards peace and security where its interests are at stake. At the same time, it also appears that China is beginning to assume the responsibilities and duties associated with a global power.

\section{Evaluation and conclusion}

Since China joined the UN in 1971, a significant evolution and change in Beijing's views and approach towards UN peacekeeping has become evident. Beijing has gradually demonstrated a more positive stance on UN peacekeeping operations and indicated greater openness and willingness to participate as a contributor to such operations.

A shift in Chinese peacekeeping policy has occurred between the Cold War and post-Cold War era, while China has continuously signalled growing confidence towards a role in the development of UN peacekeeping policy and practice. Today, China is contributing peacekeepers in substantial numbers to UN peacekeeping operations in South Sudan, Mali, Darfur and the Democratic Republic of the Congo. In doing so, China has deliberately communicated a message that its rising profile does not present a strategic threat to other major powers, but that China should be regarded as a friend to developing nations and intends to be more responsive to international expectations and the need to reduce tensions and conflicts. Borrowing from liberals and constructivists in international relations theory, China's involvement in peacekeeping has created an opportunity to assume an identity based on cooperation and partnerships relating to the solving of modern security issues and active support for international stability (Silalahi, 2016; Lanteigne, 2014). 
Realists, however, from a more sceptical point of view, will disagree with liberals and constructivists and be more inclined to offer explanations such as "[p]eace and security in Africa is suddenly in China's interests too" (Allison, 2015). They will argue that this has been particularly evident in China's increased contributions of combat personnel to UN peacekeeping operations, specifically its deployments of combat forces in recent years to Mali and South Sudan. Realists will also argue that the dramatic surge in Chinese peacekeeping participation in the 21 st century coincided with Beijing's efforts in the early 2000 s to deliberately start to expand its global economic and diplomatic influence through trade and diplomatic links. In other words, China considers participation in the activities of international organisations, including UN peacekeeping operations, as a way to expand its global influence (Wang, 2013).

The approach in this paper regarding the abovementioned theoretical debates is not to favour any one theory or school of thought over another, but rather to recognise the value of all the relevant theories in an eclectic way. From the above analysis, this article would further like to advance three broad perspectives. First, Beijing has emerged as a significant contributor to UN peacekeeping operations in general and Africa in particular. In fact, China is the only country in the global arena that significantly contributes both troops and financial means to UN peacekeeping operations. This stands in direct relation to China's growing engagement and influence in the international arena, as well as the fact that China is Africa's largest trading partner. While China's growing international role has been in accordance with its increasing peacekeeping contributions, it should also be clear that Beijing intends to demonstrate that China is a global power and regards peacekeeping as an instrument to exert greater influence on international affairs at the level of UN involvement. Unlike the US, which operates hundreds of military bases throughout the world, China has come to exercise its global presence, including in Africa, through peacekeeping operations.

Second, China's expanding role in UN peacekeeping operations over the last two decades has helped Beijing craft a positive and constructive image and reputation in the international arena. In this regard, international peacekeeping in general and peacekeeping in Africa in particular yield diplomatic benefits for China. China's participation in international peacekeeping is, in fact, an important arm or instrument of its public diplomacy, which has increasingly been aimed at projecting China and its image as that of a responsible global power. It also allows China to respond to African requests or challenges and acts as a confidence-building measure 
with both African governments and the AU as the preeminent African regional organisation. Indeed, China's peacekeeping experience shows how this emerging superpower has deliberately and systematically used peacekeeping as a diplomatic instrument to this effect.

Third, China's emerging role on the African continent is part of a pragmatic reorientation and reassessment in Chinese policy-making circles, specifically where Beijing's political interests and related investments are at stake. As its strategic and material interests have become more integrated and entangled with African concerns, Beijing has been compelled to consider its national interest and protect its growing interests in Africa more closely. As a consequence, China's growing involvement in peacekeeping has become more difficult to reconcile with Beijing's historical commitment to non-interventionism, particularly as witnessed in the case of South Sudan. In the latter case, China has had to soften or forfeit its historical arm's-length approach in view of the need to facilitate a political solution to the conflict in South Sudan and to secure its strategic interests.

Although a more proactive involvement by China in South Sudan seems to be motivated or driven by pure necessity, this is no reason to regard the case of South Sudan as a substantive future tendency for China's foreign policy and its involvement in peacekeeping operations. Although China is being forced to adopt high-risk strategies in cases of overseas investment, like in South Sudan, it is still "defined by careful impartiality" (Broga, 2014). Moreover, China's increased involvement "sits uneasily" with China's long-held policy of non-intervention (Week in China, 2016). Therefore one can safely argue that China's presence on the African continent is highly unlikely to turn into a new form of colonialism in Africa. China is certainly acutely aware of the pitfalls associated with the politics of interventionism, especially in developing nations. However, it is commonly known that China has overtaken the US as the world's largest net oil importer and it needs other mineral resources for its growing economy. This means that when and where China's strategic and related economic interests are under threat, it might require or motivate Beijing to apply at least some measure of hard power alongside soft power. After all, it would be unrealistic to expect a situation where African leaders welcome China's presence on the African continent as an acceptable alternative to the American conception of 'world order' and further encourage China's economic and commercial investments, but stay opposed to Beijing utilising its available diplomatic and even military instruments where Chinese interests and related foreign investments face risk. 


\section{Bibliography}

Allison, S. (2015). Peacekeeping in South Sudan: Is this the end for China's non-intervention policy?, Daily Maverick, 2 March. http://www.dailymaverick.co.za/article/2014-06-02-peacekeeping-insouth-sudan-is-this-the-end-for-chinas-non-interventionpolicy/\#.VQIEZY6UegY

Ayenagbo, K., Njobvu, T., Sossou, J.bV., \& Tozoun, B. K. (2012). China's peacekeeping operations in Africa: From unwilling participation to responsible contribution. African Journal of Political and International Relations, 6(2), 22-32.

Broga, D. (2014). Is South Sudan a game-changer in China's foreign policy? Global Risk Insights, 1 May. http://globalriskinsights. com/2014/05/is-south-sudan-a-game-changer-in-chinas-foreignpolicy/

Campbell-Mohn, E. (2015). China: The world's new peacekeeper. The Diplomat, 8 April. http://thediplomat.com/2015/04/china-the-worldsnew-peacekeeper/

Clingendael (Netherlands Institute of International Relations). (2015). China's role in peacekeeping and counter terrorism in Mali. Clingendael events, 30 April. https://www.clingendael.nl/event /chinas-role-peacekeeping-and-counter-terrorism-mali

Davies, M. (2008). Editorial. The China Monitor, 33, 3.

Esterhuyse, H., \& Kane, M. (2014). China-Mali relationship: Finding mutual benefit between unequal partners. Stellenbosch University Centre for Chinese Studies Policy Brief, January, 1-4.

Gill, B., \& Huang, C-H. (2013). The People's Republic of China. In A. Bellamy \& P. Williams (Eds.), Providing peacekeepers: The politics, challenges and future of United Nations peacekeeping contributions (pp.139-157). Oxford: Oxford University Press.

Hille, K. (2013). China commits combat troops to Mali. Financial Times,

27 June. http://www.ft.com/intl/cms/s/0/e46f3e42-defe-11e2-881f00144feab7de.html\#axzz3WF2Mj13D

Humphrey, B. (2013). Chinese peacekeepers in Africa? Will China step up in South Sudan's crisis? The Globalist, 19 December. http://www.theglobalist.com/chinese-peacekeepers-africa/

Kuo, L., \& Yinyin, E. H. (2016). China reacts to the death of two peacekeepers in South Sudan with grief and rage. Quartz Africa, 11 July. $\quad$ http://qz.com/728566/china-reacts-to-the-death-of-twopeacekeepers-in-south-sudan-with-grief-and-rage/ 
Lanteigne, M. (2014). China's peacekeeping policies in Mali: New security thinking or balancing Europe? NFG Working Paper, 11. http://www.diss.fu-berlin.de/docs/servlets/MCRFileNodeServlet/ FUDOCS derivate 000000004251/wp1114-china-peacekeepingpolicies-mali.pdf

Louw-Vaudran, L. (2015). China's role in South Sudan a learning curve. ISS Today, 14 December. https://www.issafrica.org/iss-today/chinasrole-in-south-sudan-a-learning-curve

Martina, M., \& Brunnstrom, D. (2015). China's Xi says to commit 8,000 troops for U.N. peacekeeping force. World News, 28 September. http://www.reuters.com/article/us-un-assembly-chinaidUSKCNORS1Z120150929

MINUSMA (United Nations Multidimensional Integrated Stabilisation Mission in Mali). (2016). MINUSMA: United Nations Stabilisation Mission in Mali, http://www.un.org/en/peacekeeping/missions/ minusma/background.shtml

Murray, C. (2013). China to deploy 'security force' to UN peacekeeping operation in Mali. U.S.-China Economic and Security Review Commission, 9 July, http://www.uscc.gov/sites/default/files/Rese arch/Backgrounder China \%20to\%20Deply $\% 20$ Security $\% 20$ Force $\%$ 20to\%20UN\%20Peacekeeping\%20Operation\%20in\%20Mali 0.pdf

Romei, V. (2015). China and Africa: Trade relationship evolves. Financial Times, 3 December. https://www.ft.com/content/c53e7f68-984411e5-9228-87e603d47bdc.

Richardson, A. (2013). Beijing's Blue Berets: UN peacekeeping and the evolution of Chinese diplomacy. The Atlantic, 13 May. http://www. theatlantic.com/china/archive/2013/05/beijings-blue-berets-unpeacekeepingand-the-evolution-of-chinese-diplomacy/275793/

Rogers, P. D. (2007). China and United Nations peacekeeping operations in Africa. NWC Review, 14 May, 73-94.

Rotberg, R. I. (2016). China can save South Sudan. China-US Focus, 24 August. $\quad$ http://www.chinausfocus.com/foreign-policy/china-cansave-south-sudan/

Shelton, G. (2008). China: Africa's new peacekeeper. The China Monitor, i33, 4-5.

Silalahi, I. (2016). China's contribution to UN peacekeeping. The Institute for Peace and Partnership Journal, 1 March. https://ippjournal. wordpress.com/about/

Smith, D. (2014). China to send 700 combat troops to South Sudan. The Guardian, 23 December, http://www.theguardian.com/world/ 
2014/dec/23/china-700-combat-troops-south-sudan-africa-battalionun-peacekeeping

Taylor, I. (2008). China's role in peacekeeping in Africa. The China Monitor, 33, 6-8.

Tiezzi, S. (2014). In South Sudan conflict, China tests its mediation skills. The Diplomat, 6 June. http://thediplomat.com/2014/06/in-southsudan-conflict-china-tests-its-mediation-skills/

Tiezzi, S. (2015). China in South Sudan: Practical responsibility. The Diplomat, 13 January. http://thediplomat.com/2015/01/china-insouth-sudan-practical-responsibility/

Tiezzi, S. (2016). Chinese peacekeeper killed in Mali attack. The Diplomat, 2 June. http://thediplomat.com/2016/06/chinese-peacekeeper-killedin-mali-attack/

Tull, D. (2006). China's engagement in Africa: Scope, significance and consequences. The Journal of Modern African Studies, 44(3), 459479.

UN Department of Peacekeeping Operations. (2001). Contributors to United Nations peacekeeping operations: Monthly summary of contributors, as of 28 February 2001. New York: UN Department of Public Information.

UN Department of Peacekeeping Operations. (2008). Contributors to United Nations peacekeeping operations: Monthly summary of contributors, as of 31 March 2008. New York: UN Department of Public Information.

UN Department of Peacekeeping Operations. (2013). Contributors to United Nations peacekeeping operations: Monthly summary of contributors, as of 30 April 2013. New York: UN Department of Public Information.

UN Department of Peacekeeping Operations. (2014). UN Mission's contributions by country. New York: UN Department of Public Information.

UN Department of Peacekeeping Operations. (2016a). Contributors to United Nations peacekeeping operations: Monthly summary of contributors, as of 31 August 2016. New York: UN Department of Public Information.

UN Department of Peacekeeping Operations. (2016b). Financing peacekeeping. New York: UN Department of Public Information. http://www.un.org/en/peacekeeping/operations/financing.shtml 
UN Department of Peacekeeping Operations. (2016c). UN Mission's summary detailed by country. New York: UN Department of Public Information.

Vasselier, A. (2016). Chinese foreign policy in South Sudan: The view from the ground. China Brief, 16(3). http://www.jamestown. org/programs/chinabrief/single/?tx ttnews $\% 5 \mathrm{Btt}$ news $\% 5 \mathrm{D}=45658$ \&\#.V-KBmv197IU

Wang, B.W. (2013). The Dragon brings peace? Why China became a major contributor to United Nations peacekeeping. Stimson Center Spotlight, 12 July. http://www.stimson.org/spotlight/the-dragonbringspeace-why-china-became-a-major-contributor-to-unitednationspeacekeeping

Week in China. (2016). Power and Glory, 22 July. https://www.weekinchina.com/2016/07/power-and-glory/

Yincai, L. (2016). China's evolving role in peacekeeping. Global Times, 7 June. http://www.globaltimes.cn/content/987443.shtml 